inquiries into the actual needs of the case. It is also essential, however, to make clear to empluyers and workpeople that the Factories Act has not gone by the board, and that hours must be regulated, through its machinery, in accordance with a considered policy. The policy was pursued of reviewing the position at individual factories at fairly short intervals, especially during the first months of the War. Orders authorizing extended hours have been made in respect of 2,459 factories, but the hours authorized were often shorter than those applied for, and some applications were refused altogether. Many factory occupiers to whom orders were granted in September and October allowing 57 hours for women have been able to maintain the necessary output with fewer working hours by means of reorganization, and in 239 cases on expiry of the order the occupiers have not desired renewal. A system of two day-shifts has been authorized for 299 factories, but applications to employ women at night have been relatively few and confined almost entirely to armament or allied factories; altogether 57 such orders have been made.

Orders have been made for thirty factories allowing the employment of male young persons more than sixteen years of age in a system of two day- and night-shifts or three eight-hour shifts. In the early weeks of the War many firms, particularly in the engineering industry, and firms engaged in making blinds and other articles urgently required owing to lighting restrictions, were permitted to employ young persons less than sixteen years old up to 47 or 48 hours a week for a short period, rarely longer than two months. Many factory occupiers took such effective measures during the period of the concession that when their orders expired it was unnecessary to employ these young persons beyond the statutory maximum of 44 hours. During the early months of the War, short-term orders permitting the employment of young persons under sixteen up to 48 hours a week were granted to 439 factories, of which 302 were engaged in general engineering and 48 in shipbuilding and marine engineering; 312 of these orders were not renewed, but at the end of the five months under review 133 such orders were in operation. The report states that it is the policy of the Government not to authorize hours which in the light of experience and of scientific investigation are detrimental to health or efficiency.

\section{The Higher School Certificate Examination}

THE Higher School Certificate Examination, about which there has recently been an investigation, has two functions: to provide a test of sixth form work and to help in the selection of State and local Education Authority scholars. For the latter purpose the investigators recently appointed to investigate the position of these examinations suggest that they are less suitable than the examinations for open scholarships at the universities, and they also say that the work of non-scholarship candidates is cramped by their association with the others. Yet they found that the exam- ination achieves its double purpose with a fair measure of success and they have not recommended drastic changes. Points for and against two alternative proposals are discussed in a report recently issued (The Higher School Certificate Examination: being the Report of the Panel of Investigators appointed by the Secondary School Examinations Council to enquire into the Eight Approved Higher School Certificate Examinations held in the Summer of 1937. Pp. 93. London: H.M. Stationery Office, 1939. 1s. $6 d$. net). The first is that the task of recommending candidates for the award of State scholarships might be handed over to the universities. The second alternative is that the examination might be divided into two parts, one of which would serve for awards of certificates and as a qualifying test for candidates for scholarships, and the other would be entirely competitive. The competition itself would then be conducted by a new central examining body.

The investigators found that the regulations tended both to enrich the larger examining bodies and to impoverish the modern universities, and they have made a simple proposal about the distribution of scholarships which is designed to correct these tendencies. Although the investigators have stated the facts and explained the difficulties clearly, the report seems inconclusive in many respects. It may be no worse for that, yet it is all the more disquieting on nearing the end of the report to find four pages of almost unrelieved condemnation of the science syllabuses and papers, and by implication of the work of the science sixth forms in schools. It is impossible fairly to summarize the statements made on these concisely written pages, but the gist of the matter is that the training of these candidates is too remote from the ordinary affairs of life, that the humanistic and cultural aspects of science generally receive scant attention, and that pupils are not helped to realize how closely scientific discoveries affect human progress or their own life and work. Severe criticism of this sort calls for some response, and the first step towards reform is that those who are engaged in the teaching and examining of science at the Higher School Certificate stage should read this report in a spirit of self-examination. If they do so it is probable that only the unimaginative will award themselves very high marks for their work.

\section{A Pioneer Wireless Station}

A Memorial stone in grey Cornish granite has been erected at Alum Bay in the Isle of Wight to mark the position occupied by the first permanent wireless station. The Needles Wireless Telegraph Station holds a place of honour in the history of wireless communication because it was here, in 1897, after a few experiments on Salisbury Plain and other places, that Marconi and the engineers of Marconi's Wireless Telegraph Co. carried out experiments which led to the great achievement of spanning the Atlantic by wireless from Poldhu in 1901. It is claimed that the Needles Station was the first from which a paid marconigram was transmitted on June 3, 1898. The 
working of this Station was inspected by many prominent people, among them being Lord Tennyson and Lord Kelvin.

The first two paid wireless messages ever dispatched were sent by Lord Kelvin, one to Sir William Preece at the General Post Office on June 3, 1898, and the other to Sir George Stokes, the Cambridge physicist. Lord Kelvin insisted on paying for the messages as an indication of his belief in the possibilities of wireless communication at a time when there was much scepticism. A photograph of the memorial to Marconi on the cliffs of Alum Bay appears in The Times of April 11. Four bronze plaques are attached to the memorial; one pays tribute to "Marconi and his collaborators, who carried out from Dec. 6, 1897, to May 26, 1900 , a series of experiments which constituted some of the most important phases of their early pioneer work in the development of wireless communication of all kinds". Another records the production of the Transatlantic Times in 1899, the first newspaper to be produced at sea, which received information by wireless telegraphy from the Needles Station and printed it in the United States liner St. Paul.

\section{Croydon Natural History and Scientific Society}

Is was on April 6, 1870, that the Croydon Microscopic Club, the forerunner of the Croydon Natural History and Scientific Society, held its inaugural meeting, so the Society is practically a contemporary of NATURE. According to the early records, about a hundred and fifty were present at the meeting, "not all of the savantissime school, it is true-but the majority evincing an earnest desire for the pursuit of science in one of its most interesting branches". Microscopical demonstrations were arranged. The chair was taken by Mr. H. Lee, who reported that the Club included three fellows of the Royal Society, four of the Linnean Society, three of the Geological Society (one of whom was treasurer of the Club), and several members of the Royal Microscopical Society and the Quekett Microscopical Club. Among the speakers were Frank Buckland and Dr. J. S. Bowerbank, F.R.S.

Further meetings were held during 1870. On May 4, J. W. Flower read a paper on the microscopical organisms of the flints. On May 14, the Club formed a party with members of the Quekett to explore the River Wandle for freshwater organisms. The quest was apparently not very successful, but mention is made of the fact that the party managed to obtain adequate refreshment of bacon and eggs, cold beef, tea, etc., at the "Greyhound". On May 28, the Club visited the house and grounds, at Park Hill, of Mr. Flower, who "had provided 2 cart loads of Flints for them to crack" in search of fossil foraminifera, etc.; "the popping of champagne corks was frequently heard above the sound of the geological hammers". On July 30, Mr. H. W. Peek, M.P., entertained the Club, and on November 30, the Club's first soirée, with exhibits, was held in the Public Hall, Croydon. Lest it be thought that undue prominence was given to refreshment of the body rather than the mind, we hasten to add that the Croydon Natural History and Scientific Society, the honorary secretary of which is Capt. B. V. Pring, 33 The Windings, Sanderstead, Surrey, has a distinguished scientific record and normally holds regular meetings twice a month at the Central Library, Croydon.

\section{Bacteriological Warfare}

IN his inaugural thesis (Thèse de Paris 1940, No. 19) on the experimental production of epidemics and epizootics, Dr. Ernest Sarfati states that the question of bacteriological warfare formed the subject of an inquiry in 1923 by a committee of experts including Profs. Bordet of Brussels, Cannon of Harvard, Madsen of Copenhagen, and Pfeiffer of Leipzig. As the result of the inquiry a protocol was issued at Geneva on June 17, 1925, signed by representatives of Germany, the United States, Great Britain, France, Italy, and about forty other nations who undertook that their countries would not take part in bacteriological warfare, the possibility and dangers of which they fully recognized. The experts classified the mode of transmission of bacteria into an enemy country as follows: (1) transportation by aircraft or spies ; (2) dispersal of microbic cultures in liquid or solid form ; (3) transmission by intermediate hosts such as rats or lice, or the poisoning of projectiles or steel weapons.

The epidemics which theoretically might be produced artificially by these means include malaria, yelıow fever, bacillary dysentery, diphtheria, typhus, plague, cholera, enteric fever, Malta fever, tuberculosis, smallpox, influenza, rabies, poliomyelitis and epidemic encephalitis, while the principal epizootics would be glanders, anthrax, foot-and-mouth disease, peri-pneumonia of eattle, and pernicious anæmia of horses. Special circumstances, however, are required to produce epidemies and epizootics, and attempts have repeatedly been made to destroy certain animal species, particularly locusts, without success. Dr. Sarfati comes to the conclusion that while bacteriological warfare is not impossible, it would only succeed in strictly localized areas, in which case the ordinary methods of prophylaxis, including the use of serums and vaccines, would prevent the spread of infection.

\section{Sir Leonard Woolley and Indian Archæological Studies}

As anticipated, the reception accorded by Indian opinion to Sir Leonard Woolley's report on the Archæological Department and the state of archæological research in Indis can only be described as mixed. To a great extent, eriticism of its findings has been inspired by umbrage taken that his expert advice should have been invited by the authorities and his verdict received and published, without sufficient regard being paid to the views and opinions of those among the Indians themselves considered competent to judge. Thus it may be considered that it was to some extent a reaction against any attempt on the part of the Government to restrict existing archæological activities in the field that was responsible for the resolution of the Archaic and 